2008-02-01

\title{
Macroeconomic Policy Change: Ireland in Comparative Perspective
}

John Hogan

Technological University Dublin, john.hogan@tudublin.ie

Follow this and additional works at: https://arrow.tudublin.ie/buschmarart

Part of the American Politics Commons, and the Political Theory Commons

\section{Recommended Citation}

Hogan, J.: Macroeconomic policy change: Ireland in comparative perspective. Irish Political Studies, 23 (1). pp. 75-97. ISSN 0790-7184. 2008.

This Article is brought to you for free and open access by the School of Marketing at ARROW@TU Dublin. It has been accepted for inclusion in Articles by an authorized administrator of ARROW@TU Dublin. For more information, please contact arrow.admin@tudublin.ie, aisling.coyne@tudublin.ie,gerard.connolly@tudublin.ie. 


\section{Macroeconomic Policy Change: Ireland in Comparative Perspective}

Total Word Count: 6,846

\begin{tabular}{|l|l|}
\hline David Doyle, & John Hogan, \\
School of Law and Government, & Faculty of Business, \\
Dublin City University, & Dublin Institute of Technology, \\
Glasnevin, & Aungier Street, \\
Dublin 9, & Dublin 2, \\
Ireland & Ireland \\
Email: david.doyle@dcu.ie & Email: john.hogan2@mail.dcu.ie \\
\hline
\end{tabular}




\title{
Macroeconomic Policy Change: Ireland in Comparative Perspective
}

\begin{abstract}
This paper sets out to develop an improved framework for examining critical junctures. This a priori framework is a significant improvement over existing critical juncture frameworks that lack any predictive element. It is an advance for historical institutionalism in particular, and political science in general. After the new framework is set out in detail here, it is tested. The framework is used to examine a number of potential critical junctures in macroeconomic policy, drawn from Ireland, Sweden, Britain, and America in the latter half of the twentieth century.
\end{abstract}

\section{Introduction}

Institutionalists (Christensen, 1997; Gorges, 2001; Mahoney, 2000; Pierson, 2000; Steinmo, 1989; Thelen and Steinmo 1992) argue that crises result in abrupt changes. They divided the past into normal periods, and critical junctures. However, Pierson (2004: 5-6) points out that critical junctures, 'a key concept underpinning the analyses of temporal processes, have received only limited discussion.' For Thelen (1999: 388) good tools for understanding continuity have not been matched by those for understanding change.

Scholars have not developed a rigorous or predictive framework for examining critical junctures. This paper will do so by hypothesising that a critical juncture in macroeconomic policy consists of three stages: macroeconomic crisis; ideational change; and radical policy change. Based upon this, we set out a framework for identifying critical junctures. As Hall (1993: 277) encourages that broad concepts be examined through numerous cases, we test our framework on four potential macroeconomic crises. From the findings we develop a set of a priori criteria for examining potential critical junctures in future. 
The first section discusses the critical junctures literature, the second sets out the criteria for case study selection, while the third examines issues relating to economic policy change. The fourth section sets out the three-stage analytical framework, the fifth tests the framework's capacity to identify macroeconomic crisis, while the sixth tests its ability to identify ideational and policy change in the wake of macroeconomic crisis. The conclusion discusses wider applications of the framework.

\section{Section 1: Characteristics and Uses of the Critical Junctures Approach}

The literature on critical junctures sees them as branching points, resulting in the adoption of one course of action from among alternatives (Mahoney, 2000: 512). Thereafter, developments continue along that particular path (Mahoney, 2003: 53; Pierson and Skocpol, 2002: 9). Pierson (2004), however, argues that institutional stability can also result from non-path dependent causes, implying that the concept should not be defined by path dependence.

For some, a critical juncture may be brief, while for others it can be a long affair (Mahoney 2001). Collier and Collier (1991) set out a framework for identifying critical junctures in development in Latin America. Their definition does not suggest that institutional change occurs quickly (Thelen, 2004: 215). For Mahoney (2001), analysing the nineteenth century liberalisation of Central America, critical junctures lasted decades, while their after effects were shorter. Hogan $(2005 ; 2006)$ questioned if these periods were in fact incremental change; labelled conversion by Streeck and Thelen (2005).

Critical junctures have also been used in research into short-term change. Garrett and Lange (1995: 628) showed that electoral landslides create critical 
junctures - mandates for policy change. Casper and Taylor (1996) employed critical junctures in analysing liberalisation in authoritarian regimes. Haggard (1988: 91) argued that economic depressions lead to questioning of existing institutions, and dramatic change. Karl (1997) employed the concept in analysing the "petro-states" development paths, Gal and Bargal (2002) used it to analyse occupational welfare in Israeli, while Hogan $(2005 ; 2006)$ revised the framework to examine change in trade union influence over public policy.

Collier and Collier (1991: 35) state that the contribution of the critical junctures concept is its focus on historical causes. However, if focusing on the formative moments of institutions is critical, only being able to do so long afterwards is a significant weakness.

\section{Section 2: The Countries Selected for Examination}

By studying politics comparatively we can discover trends and achieve an understanding of broader characteristics (Blondel, 1995: 3). The value of comparison is the perspective it offers, and its goal of building a body of increasingly complete explanatory theory (Mayer et al., 1993; Mahler, 1995). But, as Lieberman (2001: 5) also recommends, in addition to cross country cases, comparative historical analyses covering longer time spans is also beneficial. Thus, in order to provide a range of different, but comparable cases, we draw our case selection from four countries spread across four decades.

Ireland, Britain, America and Sweden are selected for examination based upon "most similar" and "most different" criteria. The requirements for "most similar" were long-standing democracy, and advanced capitalist state. The specific criteria were stable democracy since the first half of the twentieth century, and founding membership of the Organisation for Economic Cooperation and Development (OECD). These conditions tied together the principles of representative democracy and free market economy. We utilised Lijphart's (1999) categories of majoritarian and consensual democracies as the "most different" basis for selection, allowing us to control for varying institutional arrangements.

All of these countries' economies are very different, while their performances during the latter half of the twentieth century, along with the policies governing them during that time, have varied dramatically. Nevertheless, their similarities ensure 'the contexts of analysis are analytically equivalent, to a significant degree,' while their differences place the 'parallel processes of change in sharp relief' (Collier, 1997: 40). In comparison to Ireland, 


\section{the other countries provide an array of economic experiences and political contexts that should help us in making sense of developments in Ireland.}

\section{Section 3: The Issue of Change in Economic Policy}

Policy change often follows policy failure (Walsh, 2006: 490). External shocks are often blamed for policy change (Greener, 2001). There is a longstanding debate on the relationship between economics and policy change (Haggard and Kaufman, 1995: 3). However, change in economic policy is complex and must be seen in the context of societal and political change (Feldstein, 1994). This means that change in economic policy cannot be studied in isolation (Taylor, 1995). We will test our hypothesis in three discrete stages, each of which will employ observable implications incorporating aspects of societal and political change.

An economic crisis can unleash powerful forces of change into an economy that can have a wide impact (Haggard, 2003). Solimano (2005: 76) argues that an economic crisis can be identified by examining indicators of growth, inflation, employment creation, and poverty reduction.

Crisis implies prevailing policy cannot be sustained without continued deterioration (Haggard and Kaufman, 1995: 14). An economic crisis, therefore, influences policy preferences (Stevenson, 2001: 621). New ideas can change the policy environment (Pemberton, 2000: 790). But, how ideas influence policy is something theorists have long grappled with (Taylor, 1993). This gives rise to questions such as: Where do ideas come from? How do they relate to failing policies? And, why does the paradigm underlying a failing policy sometimes change, resulting in policy change, whereas at other times it remains unaltered? To examine this we will look at how society, and policy actors, regard current economic policy and the alternatives. 
The impact upon society of economic policy change is dependent on the nature of that change. If change in economic policy is minor, the overall impact upon society can be negligible. Whereas, if change in economic policy is radical the impact upon society can be significant. To examine the nature of change in economic policy we draw upon the work of Hall (1993), which ties together the concepts of policy change, societal learning, and the state.

\section{Section 4: Analytical Framework}

This is a three-stage framework, derived from our hypothesis. Initially the framework concentrates on economic crisis identification. If we can identify a crisis we have identified an area where existing policy will come under attack. This leads to the second stage, identification of ideational change. If new ideas, providing a viable alternative to the current paradigm, are adopted, ideational change is confirmed. The final stage is policy change identification - the dependent variable. The level of policy change depends on the preceding variables, but also determines if there is a critical juncture in macroeconomic policy, as radical policy change is integral to our hypothesis.

\subsection{Identification of Macro-economic Crisis}

'The literature on critical junctures views them from the perspective of crises, placing a particular emphasis on the tensions leading up to the critical juncture' (Collier and Collier, 1991: 32). 'Traditionally, students of institutional change focused on the importance of crisis' (Cortell and Peterson, 1999: 184). 'Exogenous shock is often cited as an explanation for policy change' (Golob, 2003: 373). Here the crises tested for are macro-economic. 
We develop a range of observable implications to identify a macro-economic crisis as a severe economic low point. Apart from the first observable that is directly quantifiable, identification of empirical-theoretical fit for the remainder relies upon the clarity of the results provided by the independent variables utilised.

01. If the main economic indicators reached decade-long lows the economy may have been in crisis.

O2. If opinion polls find the public regarded the economic in crisis, then the economy may have been in crisis.

O3. If the national media regarded the economy in crisis, then the economy may have been in crisis.

O4. If economic and political commentators regarded the economy in crisis, then the economy may have been in crisis.

05. If the central bank regarded the economy in crisis, then the economy may have been in crisis.

O6. If both domestic and international organisations monitoring economic performance regarded the economy in crisis, then the economy may have been in crisis.

07. If elected representatives regarded the economy in crisis, then the economy may have been in crisis.

O8. If government pronouncements on the economy were consistent with a crisis management approach, then the economy may have been in crisis.

\subsection{Identification of Ideational Change}


For Greener (2001: 134) exogenous shocks result in a new policy paradigm. However, we hypothesise that macro-economic crisis is a necessary, but insufficient, condition for change in economic policy. A macro-economic crisis may result in idea generation, and the consolidation of agents around a new ideational paradigm. Ideational change, if it has occurred, may then lead to policy change. Therefore ideational change stands between a crisis and policy change, determining if a crisis will result in a policy change. This corresponds to McNamara's (1998: 4-5) argument that actors utilise new ideas to chart new policy strategy.

A crisis can discredit previous policies due to their inability to right the situation. Economic crises can generate a range of alternatives, but policy choice remains 'centred in domestic political and ideational processes' (Golob, 2003: 375). When an economic model is in difficulty windows of opportunity appear in which agents challenge the existing paradigm (Kingdon, 1995). They will present a range of new ideas to replace the ones upon which existing policy is based. We contend that significant policy change is dependent upon agents reaching consensus upon, and consolidating around, a particular set of ideas. This is similar to Blyth's 'discursive phase,' where 'agents interested in reforming existing distributional arrangements contest the definition, meaning and solution to the problems identified by opposing economic ideologies' (1997: 234).

We contend that new ideas are introduced into the policy domain by three groups of change agents. Combinations of these change agents constitute the policy networks discussed by Hall (1993). The most important are what Dahl (1961) termed 'political entrepreneurs.' Political entrepreneurs 'exploit moments of instability' and 'invest resources in the creation of a new policy, a new agency, or new forms of collective action' (Sheingate, 2003: 188-190). In a crisis, a political leader, usually an 
opposition leader, will seek out new economic policy ideas to rectify the ills of the existing paradigm. The second group are Kingdon's (1995: 179-183) 'policy entrepreneurs.' These are agents who spread ideas to replace the current paradigm. They may be civil servants, technocrats, academics, economists and interest groups, who have access to decision makers. The final group consists of outside influences: the media, the OECD, IMF and the World Bank. They critique an existing economic paradigm, advocating a new one. Both policy entrepreneurs and outside influences are responsible for producing ideas, but the political entrepreneur acts as a figurehead, introducing these ideas into the policy process. As Thatcher quipped to Ralph Harris of the Institute of Economic Affairs (IEA), when he claimed the IEA had been advocating market reform for two decades prior to her time, 'Ralph, the cock may crow but it's the hen that lays the egg., ${ }^{1}$

These three broad groupings are similar to those identified by Pemberton in his schema of policy learning (2000: 777). He notes that while minor policy changes emanate from administrators, significant changes are dominated by networks made up of academics, economists, interest groups, the media, and in particular politicians. The triumph of a new idea depends upon 'a workable new idea being available' which change agents are prepared to promote (Oliver and Pemberton, 2004: 419).

The observables suggest that as agents debate the viability of the old economic model, they generate solutions to its ills through new ideas.

O1. The media questions the efficacy of the current economic model and/or specific policy areas.

\footnotetext{
${ }^{1}$ Financial Times, 20 October, 2006, p.15.
} 
O2. Opposition political parties critique the current model and propose alternative economic ideas - at election time their platform will be built around these alternative ideas.

O3. Civil society organisations, e.g. labour unions, employer organisations, consumer groups etc. critique the current model, reflecting Hall's coalition-centred approach (1989: 12).

O4. Widespread public dissatisfaction with the current paradigm, observable through opinion polls, protests etc.

O5. External or international organisations critique the current model and/or actively disseminate alternative economic ideas to replace this model.

O6. A clear set of alternative economic ideas are evident.

07. A clear agent of change (political entrepreneur) to inject these new ideas into policy arena is evident.

According to Legro's (2000: 419) two-stage model of ideational change, if agents agree that the existing ideational paradigm is deficient and should be replaced, the first stage - ideational collapse - has occurred. Agents will propose a range of solutions, with one main challenger to the dominant creed. However, 'even when ideational collapse occurs, failure to reach consensus on a replacement could still produce continuity, as society reflexively re-embraces the old orthodoxy' (Legro, 2000: 424). The crucial issue is reaching consensus on a new set of ideas. If consensus is achieved it marks the second stage of Legro's model - consolidation agents coordinating a replacement set of ideas. This can be seen in political entrepreneurs consolidating innovations by combining a mixture of interests to produce a winning coalition (Sheingate 2003: 192-193), thus, highlighting that the 
presence, and role, of political entrepreneurs is central to the process of ideational change.

\subsection{Identification of Policy Change}

Pemberton (2000: 790), like McNamara (1998) argues that new ideas change the wider policy environment. The level of policy change is dependent upon the preceding variables, but is also central to determining if there has been a critical juncture. We hypothesise that once there is political entrepreneur led consolidation around a new set of ideas, a significant policy change should follow. We argue that ideational change constitutes the "differentiating factor" between crises that result in radical policy change, and those that do not. Therefore, we must discover if radical changes in economic policy follow ideational change. The observable implications used here are based upon Hall's (1993) concepts of first, second, and third order policy change. Hall (1993: 291) argued that exogenous shocks, and policy failures, discredit the old paradigm, leading a re-examination of the belief systems through which that policy was created - a paradigmatic change. He describes rare, but radical, and overarching changes in policy as third order changes. The observables set out below enable us identify, and differentiate, both the normal and fundamental shifts in macroeconomic policy. They also incorporate the idea of swift and enduring change developed by Hogan (2005). As we are dealing with the concept of a critical juncture (radical change) we must assume this is not a long process, otherwise it would constitute incremental change. Also, if the change is to endure in an environment full of competing actors, policy entrepreneurs, and policies in search of a home, it should survive for at least one change of government. A paradigm shift in economic policy must encompass each of these observables. 
O1. If economic policy instrument settings changed (swiftly and for longer than one government's term of office) there may have been a radical change in government economic policy.

O2. If the instruments of economic policy changed (swiftly and for longer than one government's term of office) there may have been a radical change in government economic policy.

O3. If the hierarchy of goals behind economic policy changed (swiftly and for longer than one government's term of office) then there may have been a radical change in government economic policy.

As space permits only a brief review of the material examined we concentrate on cases that will highlight the framework's analytical flexibility.

\section{Section 5: Identification of Macroeconomic Crises}

Ireland 1957-1959

In 1956 a stagnant and closed Irish economy was finally opened to foreign investment. This was an admission of the failure of the economic philosophy underlying protectionism. However, this single act did not right the economy. By 1959 international organisations, the media, the central bank, and national commentators regarded the economy as in dire crisis. All economic indicators were at low ebb. The OECD (1962: 6) stated that per capita GNP grew at 2.4 per cent per year throughout the 1950 s only because 'net migration averaged forty-one thousand a year.' However, this growth rate was among the lowest in the OECD (OECD, 1962:

6). Ó'Gráda and O'Rourke (1995: 214) argue that 'in the 1950s, Ireland's relative 
[economic] performance was disastrous.' Taoiseach Lemass stated that 1959 was a crucial year for consolidating the economic foundations of political independence. ${ }^{1}$ The leader of opposition remarked that the magnitude of the economic crisis could only be righted by a tremendous effort. ${ }^{2}$ The consensus pointed to a crisis in the economy.

Britain 1969-1970

During the 1960s Britain's relative economic decline brought into question Keynesian policies. National commentators, the media, the Bank of England, and domestic and international organisations, regarded the economy as in difficulty by 1970 . Hodgkinson (1971: 1) observed that the five problems with the economy were inflation, unemployment, industrial relations, low growth of production, and uncertainty over Europe. The Economist pointed out that unemployment ${ }^{2}$ was at its highest level since May 1940³, while the OECD (1970: 5) found inflation at its highest level in 18 years. The Guardian argued that inflation was the most serious problem confronting the government. ${ }^{4}$ The Bank of England (1971: 3) observed that between March and June 1970 economic grow was lethargic, while industrial costs rose rapidly. Days lost to industrial disputes stood at a post-war high of 11 million (OECD, 1970: 12). The National Institute of Economic and Social Research's (NIESR) (1970) predicted little economic growth. Although there were problems with inflation and growth, overall the economy was not regarded as in crisis.

\section{America 1979-1981}

\footnotetext{
${ }^{2}$ The Economist, 20-26 June, 1970, p. 73.

${ }^{3}$ Time International, 1 June, 1970. Vol. 95, No. 22, p. 27.

${ }^{4}$ The Guardian, 8 June, 1970, p. 10.
} 
The Carter administration's final year was characterized by high interest rates, and rising unemployment (OECD, 1982: 9). Compounding matters, the National Bureau of Economic Research declared the economy in recession. ${ }^{3}$ When the President invoked the Credit Control Act it resulted in reduced borrowing, and a steep decline in growth. ${ }^{4}$ By 1979 , inflation stood at 11.3 per cent, rising to 13.5 per cent in 1980 , while GDP growth struggled at 2.4 per cent in 1979 , before slumping to -0.3 per cent by 1980 (Mitchell, 1998). By the second half of 1980 the administration's response to the recession smacked of crisis-management. Carter's Economic Renewal Programme to stimulate the economy was heavily criticized. ${ }^{5}$ By November Fed Chairman Volcker admitted there was a recession. ${ }^{6}$ In restraining the growth of the money supply the Fed pushed interest rates to their highest levels in a century, reducing consumer borrowing, and sending spending into decline. ${ }^{7}$ 'Through the actions of the Reserve Board and the administration, the economy was inadvertently plunged into the kind of recession the White House had been trying to avoid' (Dark, 1999: 120).

\section{Sweden 1980-1982}

The recession that began in the mid 1970s proved persistent. The OECD (1982: 49) described the economy in 1982 as in difficulty. Government's expenditures had grown, while revenues stagnated. The budget deficits were financed by international borrowing (Siven, 1984: 17), and as a consequence the debt to GNP ratio increased by over 250 per cent in six years. In 1981 inflation reached 12.1 per cent, while GDP growth fell to -0.6 per cent. ${ }^{8}$ Unemployment reached 3.1 per cent in 1982 , its highest level since 1945 , a political scandal in a country accustomed to full employment. ${ }^{9}$ However, economists believed unemployment would have been closer to 16 per cent 
if it included the jobless in training programmes, workers forced into early retirement, and those who had given up looking for work. ${ }^{10}$ The New York Times argued that the Swedish economy had been hobbled by foreign debt, low investment, and an adverse balance of payments. ${ }^{11}$ The economy was in crisis.

Table 1.1 - The Identification of Macroeconomic Crisis

\begin{tabular}{|l|c|c|c|c|}
\hline The Observable Implications & $\begin{array}{c}\text { Ireland } \\
\mathbf{1 9 5 9}\end{array}$ & $\begin{array}{c}\text { Britain } \\
\mathbf{1 9 7 0}\end{array}$ & $\begin{array}{c}\text { America } \\
\mathbf{1 9 8 1}\end{array}$ & $\begin{array}{c}\text { Sweden } \\
\mathbf{1 9 8 1}\end{array}$ \\
\hline $\begin{array}{l}\text { O1. Were the main economic indicators at } \\
\text { decade-long lows? }\end{array}$ & $\mathrm{X}$ & $\mathrm{X}$ & $\mathrm{X}$ \\
\hline $\begin{array}{l}\text { O2. Did opinion polls find the public regarded } \\
\text { the economic in crisis. }\end{array}$ & & $\mathrm{X}$ & $\mathrm{X}$ & $\mathrm{X}$ \\
\hline $\begin{array}{l}\text { O3. Did the media regard the economy in } \\
\text { crisis? }\end{array}$ & $\mathrm{X}$ & $\mathrm{X}$ & $\mathrm{X}$ & $\mathrm{X}$ \\
\hline $\begin{array}{l}\text { O4. Did economic and political commentators } \\
\text { regard the economy in crisis? }\end{array}$ & $\mathrm{X}$ & $\mathrm{X}$ & $\mathrm{X}$ \\
\hline $\begin{array}{l}\text { O5. Did the central bank regard the economy as } \\
\text { in crisis? }\end{array}$ & $\mathrm{X}$ & $\mathrm{X}$ & $\mathrm{X}$ & $\mathrm{X}$ \\
\hline $\begin{array}{l}\text { O6. Did domestic/international organisations } \\
\text { regard the economy in crisis? }\end{array}$ & $\mathrm{X}$ & $\mathrm{X}$ & $\mathrm{X}$ \\
\hline $\begin{array}{l}\text { O7. Did elected representatives regard the } \\
\text { economy in crisis? }\end{array}$ & $\mathrm{Y}$ & $\mathrm{N}$ & $\mathrm{Y}$ & $\mathrm{X}$ \\
\hline $\begin{array}{l}\text { O8. Were gov pronouncements on the economy } \\
\text { were consistent with a crisis management } \\
\text { approach? }\end{array}$ & $\mathrm{X}$ & $\mathrm{X}$ \\
\hline Economic Crisis & & & \\
\hline
\end{tabular}

Of the four potential crises, Britain 1970, satisfying only two observables, was not a macroeconomic crisis. As a result the British case is dropped here. The next section examines if ideational change occurred following the confirmed macroeconomic crises, and, central to our hypothesis, if radical policy change followed in the wake of ideational change.

\section{Section 6: Identification of Ideational and Policy Change}

Ireland 1959

Irish economic stagnation during the 1950s led to 'vigorous debate on the economy' (O’Day, 2000: 27). This debate, conducted at national levels, among civil society groups, and within the media, aggressively questioned the efficacy of protectionism. 
In turn, it was heavily influenced by the propagation of Keynesian ideas, or planned capitalism that was gaining salience in the US, and in much of Europe. The ideas associated with the outward looking strategy that Ireland eventually adopted were first utilised by the coalition government of 1954-57. They were tentatively employed in the 1956 decision to allow the IDA distribute grants to export-orientated industries, and the creation of the Export Profits Relief Tax (Suarez, 2001). The Irish economy abandoned its traditional policy of protectionism and opened up to foreign investment for the first time (Tansey, 1998: 12).

These innovations, although doing little to alleviate the economic woes, were supported by employer groups and the trade unions (Suarez, 2001). As such, these moves, though only tentative, and the resultant media debate critiquing the old model of protectionism, ensured that the year ' 1957 is conventionally thought of as the end of an era, as making the final exhaustion of the ideas of the first generation of political leaders' (Garvin, 1982: 37). In an environment of disappointing economic performance, contestation of the existing economic orthodoxy by agents agreed on both its inadequacy, and need for replacement, resulted in its collapse.

The 1957 election was fought by Fianna Fail on a platform attacking the old economic model, and the economic stagnation that had prevailed. As Hall argues 'politicians compete for office precisely by propounding new solutions to collective problems which appeal to the electorate' (Hall, 1993: 289). Fianna Fail won the election, and Sean Lemass became Minister for Industry and Commerce.

'On his return to office in 1957 [Lemass] began the gradual process of opening the state to foreign investment' (Girvin, 1994: 125). This was despite fears over protected Irish industry. ${ }^{12}$ Poor economic performance prompted this fundamental reappraisal of the policies pursued since the 1930s. This reappraisal was 
embodied in the White Paper First Programme for Economic Expansion drawn up by the Department of Finance.

In this regard Lemass was heavily influenced by the ideas of T.K. Whitaker, as set out in Economic Development. Whitaker is a policy entrepreneur in this instance, as his ideas formed the backbone of the 1958 White Paper First Programme for Economic Expansion (Horgan, 1997). This document laid out a coherent set of new economic ideas, based on an outward looking strategy and/or planned capitalism.

With the retirement of DeValera in 1959, Lemass became Taoiseach. The state of the economy, and the new ideas propagated by Lemass and Whitaker, caused opposition parties to coalesce around these ideas such that, during the Dail debate on Lemass' election as Taoiseach, Daniel Desmond of the Labour Party argued it was time for the political establishment to realise that solving the problems with the economy superseded their own struggles for power. ${ }^{13}$ A broad range of agents had reached consensus on a replacement set of economic ideas, consolidating a new dominant ideational orthodoxy. Lemass now had the mandate and opportunity to inject these new ideas into the policy arena.

Lemass, as Taoiseach, displayed a vigorous entrepreneurial leadership (McCarthy, 1973: 22). He identified the need for change in industrial development policy. ${ }^{14}$ Tax breaks and grants were provided to foreign firms wishing to set up in Ireland. Under Lemass, an outward-orientated economic strategy became the bedrock of Irish economy policy (O’Donnell, 1998: 4). Adjusting industries to competition led public policy into the realms of industrial relations, and pay bargaining. Lemass understood that government had to play a more active role in the Irish economy, but realised that the success of this strategy assumed a new partnership with different interest groups, which would become players in the policy game (Murphy, 1997: 58). 
The trade unions and employer organisations were brought into the policy-making environment, through Employer-Labour Conference. 'The dialogue between state and major socio-economic groups quickly acquired a regular and institutional character' (Peillon, 1995: 370). For the OECD (1961: 12) the Fianna Fail government's 1958 and 1959 budgets marked a clear change in fiscal policy. By 1961, the reshaping of public capital expenditure to emphasize directly productive investment had stimulated economic growth. The OECD (1961: 10) found that the policy of grants and tax exemptions attracted a substantial amount of foreign capital to Ireland.

The late 1950s, a time of economic crisis, witnessed a dramatic shift in Irish economic policy. Lemass, acting as a political entrepreneur, fostered alternative ideas on how the economy should be run. Around these ideas consensus developed, leading to their consolidation. Thereafter, the setting, instruments, and hierarchy of goals behind Irish economic policy changed. The decision to open the economy to foreign investment was an admission of the failure of protectionist policy. An economic crisis led to the collapse of the old economic orthodoxy, the consolidation of a new economic ideational structure, and a third order change in economic policy - a critical juncture according to our hypothesis

\section{America 1979-1981}

By the end of Carter's administration the US economy was in trouble. Paul Volcker, Federal Reserve Chairman, believed the remedy for spiralling inflation was a tightened money supply (Krugman, 1990), the first move towards monetarist policy. However, the results were limited. The president's imposition of new controls on 
consumer credit contributed to the economy's slide. There was widespread dissatisfaction with, and critiques of, government policy.

Time argued that Carter's decisions resulted in reductions in consumer borrowing, and a steep decline in growth. ${ }^{15}$ 'Recession Hits Hard' headlined The Washington Post. ${ }^{16}$ Economic commentators were pessimistic about the prospects for recovery. The economy was in what Walter Okun called 'the great stagflation swamp. ${ }^{17}$ The President's inflation record is not good admitted Walter Heller. In allowing the economy to deteriorate, noted Alan Greenspan, Carter was forced into a crash programme of restraint leading to a huge rise in unemployment. ${ }^{18}$ The critiques began to coalesce around a set of alternative economic ideas purporting to tackle current economic ills: monetarism. With change agents in agreement on the inadequacy of the existing paradigm, ideational collapse had occurred.

Monetarist concepts had been present in American political circles since the early 1970s, with Milton Friedman, Robert Lucas, and Arthur Laffer, founding organizations such as the American Enterprise Institute (Blyth, 1997: 236-237). These groups ensured that by the late 1970s American economic journalism spread their ideas (Blyth, 1997: 237), with the Wall Street Journal acting as both 'effective synthesizer and chief proselytizer for these...ideas' (Blyth, 2002: 164). In this respect both a clear set of alternative ideas, and policy entrepreneurs, were present.

However, it was Ronald Regan, the Republican candidate for President, who embraced this new ideology, and adopted the role of political entrepreneur. His message was lower taxes, reduced spending on social services, balanced budgets, and fewer governmental regulations. He blamed the Democrats' inflationary policies for stifling productivity, and bringing recession. In late August, Reagan stated that President Carter had 'created a severe depression. ${ }^{, 19}$ He promised new policies and 
leadership (Wayne, 1992: 182). During the final stages of the election Reagan declared Carter's record on inflation and unemployment 'a failure on a scale so vast, in dimensions so broad, with effects so devastating, that it is virtually without parallel. ${ }^{20}$ Regan forged an electoral coalition around the notion of monetarism (Blyth, 1997), and won the election on the back of having a discernable set of alternative economic ideas which could replace existing arrangements. President Reagan's election, and the accompanying Congressional election, was a clear mandate for conservative policies (OECD, 1982: 10). In the wake of an economic crisis, and with the paradigm underlying existing economic policy collapsed, change agents reached consensus, and consolidated around, a new economic orthodoxy. Monetarism's wide acceptance as a viable alternative idea marked an ideational change. With the ideas fundamental to existing policy replaced, those policies were no longer armoured, and were easily changed.

The new administration's economic policies were very different from those of its predecessors in their political roots, and theoretical foundations (OECD, 1982: 9). Reagan fashioned his economic strategy around the monetarist proposals of Arthur Laffer. To combat stagflation he promoted a painless panacea: tax cuts, and deregulation, wherein the resulting stimulus would boost federal revenues to balance the budget, reducing inflationary pressure. The new President's programme, dubbed Reaganomics, was the belief that American capitalism, freed from the burden of taxes and regulation, would surge ahead. Reagan's first budget proposed a $\$ 750$ billion tax cut over three years (Jones, 1995: 597). The administration also cut $\$ 11$ billion from public works and job training programmes, unemployment benefits programmes, and trade adjustment assistance-benefits. $^{21}$ 'A trend towards reduced economic regulation was carried further by the immediate application of the remaining stages of crude oil 
price decontrol, and the abolition of the Council on Wage and Price Stability' (OECD, 1982: 24).

In political terms Reagan capitalised on anti-government sentiment, emphasising individualism, and a smaller Federal role. Tax relief was allied to a restructuring of federal expenditure, bringing sharp changes in the economy. Economic policy instrument settings, the instruments themselves, and the goals behind economic policy, all changed. This third order change (paradigm shift) in macro-economic policy endured into the administration of Reagan's successor. D'Souza (1997: 85) argues that Reagan's programme for America was the most ambitious since the New Deal.

An economic crisis led to the collapse of the ideas underlying existing macroeconomic policy. Policy entrepreneurs advocated a replacement set of ideas, namely monetarism. Consolidation around this new economic orthodoxy was achieved with the emergence of Ronald Reagan, the political entrepreneur. Following his election there was a third order change (paradigm shift) in macro-economic policy. Here we have a macro-economic crisis, ideational change, and a radical change in macroeconomic policy, which according to our hypothesis is critical juncture in macroeconomic policy.

Sweden 1980-1982

The recession of the 1970s saw the budget deficits supporting the social welfare system deepen. By 1981 the non-socialist coalition government held only 102 of the 350 seats in the Riksdag. ${ }^{22}$ In autumn 1981 the krona was devalued by 10 per cent, and the following spring the government introduced far-reaching austerity measures. However, the opposition parties gained ground (Hadenius, 1997: 129-130). The 
government hoped its attempts to combat the economy's problems would generate respect for non-socialist policies, instead they generated widespread critiques, and initiated a debate on the economy. The Financial Times pointed out that the Swedes were nervous about the future, but reluctant to see the welfare state's benefits reduced. ${ }^{23}$ “The welfare state is in a crisis of legitimacy,' observed Hans Vetterberg, Sweden's leading public opinion analyst. 'We can no longer afford to keep expanding it." ${ }^{, 24}$ Not surprisingly, the Swedish Employers' Federation (SAF) was unhappy with the government. However, the non-socialist government wanted neither to raise taxes, nor dismantle the welfare state. ${ }^{25}$ This situation, rife with unfulfilled economic expectations, and agents dissatisfied with the prevailing paradigm, constituted ideational collapse.

The 1982 election was deemed crucial as it would determine whether public support had shifted, as in Norway and Denmark, away from the Social Democrats. The election campaign was dominated by talk of economic crisis - a $\$ 10$ billion debt to foreign banks, inflation, declining exports, and increasing unemployment. ${ }^{26}$ During the campaign the Social Democrats attacked the viability of another non-socialist government, and their economic policies. The party presented a program on how Sweden could save and work its way out of crisis. Ultimately, the election, and the debates surrounding it, failed to generate either a coherent set of alternative economic ideas to replace the existing ones, or a significant agent of change. The non-socialist parties failed to create a coalition around ideas alternative to the welfare state. Nearly all economic ideas presented were variations on existing themes. Despite the dominant orthodoxy's failure agents re-embraced it. The ideas underpinning the policies of the welfare state endured. The SAP won the election, not on the back of a 
new economic paradigm that could cure the country's woes, but on a series of proposals to correct existing economic arrangements.

The result was an altered approach to economic management, with minor changes in economic policies. The SAP, admitting there were no ready solutions to the economy's problems, ${ }^{27}$ implemented a recovery programme - The Third Road. This approach argued that renewed growth required redistribution of income from labour to capital. It constituted a shift in SAP economic planning, behind which course lay the influence of its research unit, as opposed to those of the unions. This marked an attempt to maintain a level of social democracy, which other countries were rolling back (Martin, 2000: 234). The Third Road sought to devise a wideranging stabilisation programme that included demand management measures, as well as initiatives to promote structural change and ensure the fair distribution of the burden of adjustment (OECD, 1984: 21). The SAP was also determined to pour funds into job creating industries. $^{28}$

The centrepiece of finance minister Feldt's strategy to boost corporate profits was devaluation of the krona. This measure was implemented in combination with a price freeze, and increases in sales and corporate taxes, in a sweeping "crisis plan" 29 aimed at reviving the economy. ${ }^{30}$ The main objective was to achieve export-led, and investment-fed, recovery (OECD, 1984: 21). The LO (Landsorganisationen $i$ Sverige) accommodated devaluation by demanding average wage increases of 2.5 per cent in the ensuing wage-bargaining round. The devaluation and international economic recovery resulted in high earnings and excellent scope for export expansion (Ahlén, 1989: 333). The government also restored welfare entitlements cut by the non-socialists (OECD, 1984: 23). 
To maintain the welfare state, by whatever means necessary, the government prioritized private sector growth, profits, and market forces. In this case, the economic policy instrument settings changed, but the instruments of economic policy, and the goals behind economic policy, remained much the same - the maintenance of the welfare state. This was a first order policy change.

The economic crisis in Sweden generated significant debate, and ideational collapse occurred. However, change agents did not consolidate around a replacement economic orthodoxy. As a result, the existing economic paradigm endured, providing the existing economic policies with sufficient armoured protection to remain largely intact. There was no critical juncture in economic policy.

Table 1.2 - The Identification of Ideational Change

\begin{tabular}{|c|c|c|c|}
\hline The Observable Implications & $\begin{array}{c}\text { Ireland } \\
1959\end{array}$ & $\begin{array}{c}\text { America } \\
1981\end{array}$ & $\begin{array}{c}\text { Sweden } \\
1982\end{array}$ \\
\hline $\begin{array}{l}\text { O1. Media questions efficacy of current economic model } \\
\text { and/or specific policy areas }\end{array}$ & $\mathrm{X}$ & $\mathrm{X}$ & $\mathrm{X}$ \\
\hline $\begin{array}{l}\text { O2. Opposition parties critique current model and propose } \\
\text { alternative economic ideas - at elections their platform are } \\
\text { built around these alternative ideas }\end{array}$ & $\mathrm{X}$ & $\mathrm{X}$ & \\
\hline $\begin{array}{l}\text { O3. Civil society organisations critique current model, } \\
\text { reflecting Hall's coalition-centred approach }\end{array}$ & $\mathrm{X}$ & $\mathrm{X}$ & \\
\hline $\begin{array}{l}\text { O4. Widespread public dissatisfaction with current paradigm, } \\
\text { observable through opinion polls, protests etc. }\end{array}$ & & $\mathrm{X}$ & $\mathrm{X}$ \\
\hline $\begin{array}{l}\text { O5. External/international organisations critique current } \\
\text { model and/or actively disseminate alternative economic ideas } \\
\text { to replace model }\end{array}$ & $\mathrm{X}$ & $\mathrm{X}$ & $\mathrm{X}$ \\
\hline O6. A clear set of alternative economic ideas are evident & $\mathrm{X}$ & $\mathrm{X}$ & \\
\hline $\begin{array}{l}\text { O7. A clear agent of change to inject these new ideas into } \\
\text { policy arena is evident }\end{array}$ & $\mathrm{X}$ & $\mathrm{X}$ & \\
\hline Adoption of New Economic Idea & $\mathbf{Y}$ & $\mathbf{Y}$ & $\mathbf{N}$ \\
\hline
\end{tabular}

Table 1.3 - The Identification of Change in Government Economic Policy

\begin{tabular}{|c|c|c|c|}
\hline The Observable Implications & $\begin{array}{c}\text { Ireland } \\
1959\end{array}$ & $\begin{array}{c}\text { America } \\
1981\end{array}$ & $\begin{array}{c}\text { Sweden } \\
1982\end{array}$ \\
\hline $\begin{array}{l}\text { O1. If economic policy instrument settings changed there } \\
\text { may have been a radical change in economic policy }\end{array}$ & $\bar{X}$ & $\mathrm{X}$ & $\mathrm{X}$ \\
\hline $\begin{array}{l}\text { O2. If the instruments of economic policy changed there } \\
\text { may have been radical change in economic policy }\end{array}$ & $\mathrm{X}$ & $\mathrm{X}$ & \\
\hline $\begin{array}{l}\text { O3. If the hierarchy of goals behind economic policy } \\
\text { changed there may have been a radical change in economic } \\
\text { policy }\end{array}$ & $\mathrm{X}$ & $\mathrm{X}$ & \\
\hline Critical Juncture in Macroeconomic Policy & $\mathbf{Y}$ & $\mathbf{Y}$ & $\mathbf{N}$ \\
\hline
\end{tabular}


Two of the cases examined (Ireland 1957-1959; America 1979-1981) witnessed third order changes (paradigm shifts) in macro-economic policy. These third order policy shifts occurred following macro-economic crises, collapse of the dominant economic orthodoxies, the introduction of new ideas into the policy arenas, and the consolidation of change agents around these ideas. They constituted critical junctures in macro-economic policy. However, neither of the other two cases witnessed critical junctures. In Britain 1969-1970 there was no macro-economic crisis, while in Sweden 1980-1982, although there was a macro-economic crisis, there was no ideational change. In Sweden ideational collapse followed an economic crisis, but change agents failed to consolidate around a replacement orthodoxy. The old orthodoxy endured, and the hierarchy of goals behind Swedish macro-economic policy did not change.

These findings validate our hypothesis. A critical juncture in macro-economic policy consists of three stages: macro-economic crisis, ideational change, and radical policy change. A macro-economic crisis in itself is a necessary, but insufficient, condition for a paradigm shift in macro-economic policy. A macro-economic crisis not followed by ideational change, will lead to a first (Sweden 1980-1982), or second order macro-economic policy change. Whereas, a macro-economic crisis followed by ideational change (collapse and consolidation) will lead to a third order change in the dependent variable - macro-economic policy (Ireland 1957-1959; America 19791981) - which combined equals a critical juncture.

Ideational change is crucial in determining if third order macro-economic policy change will occur after a macro-economic crisis. Existing ideational orthodoxy provides armour protection for existing policy, ensuring its continuity. However, in the wake of an economic crisis, if ideational collapse should occur, existing macroeconomic policy is no longer armoured. If change agents, led by a political entrepreneur, consolidate around a new set of economic ideas they will attempt to inject these into the policy domain. The result of this ideational change will be a third order change in macro-economic policy. However, if change agents fail to consolidate around a new economic orthodoxy, existing ideas will endure, and there will only be a first, or second, order policy change. Therefore, political entrepreneur led consolidation around a new set of economic ideas is the "differentiating factor" between an economic crisis that leads to a critical juncture in macroeconomic policy, and one that does not. This links with Pemberton's (2000: 771) argument that different network configurations are associated with different orders of policy change.

\section{Discussion: Ireland in a Comparative Perspective}

The paper sought to test a framework for examining critical junctures that incorporated an a priori element. This framework is based upon the hypothesis that a critical juncture in macroeconomic policy consists of three stages: macroeconomic crisis, ideational change, and radical policy change.

Of the cases examined, Ireland 1957-1959 and America 1979-1981 constituted critical junctures. The ideational foundations of existing macro-economic policy collapsed after economic crises. These were replaced as change agents, led by political entrepreneurs, consolidated around new economic orthodoxies. Third order macro-economic policy change followed ideational change. Britain 1969-1970 was merely an economic downturn, whereas Sweden 1980-1982 was an economic crisis. 
While ideational collapse occurred in Sweden, change agents, lacking the influence of a political entrepreneur, failed to consolidate around viable alternative ideas. Without ideational change, there was only minor policy change.

After a macro-economic crisis, established policies, having been undermined by previous failures, are liable to be overcome as change agents, led by a political entrepreneur, consolidate around new ideas. Without a political entrepreneur to focus the various change agents' interests there will be no consolidation around an alternative idea, i.e. no ideational change. In the absence of ideational change the level of policy change will be of the first (Sweden 1980-1982) or second order. Political entrepreneurs are crucial to ideational change. While policy entrepreneurs and outside influences generate ideas, political entrepreneurs consolidate these interests, and their ideas. The political entrepreneur is the bridge between old ideational collapse and new ideational consolidation. Following a macro-economic crisis, identification of ideational collapse, and subsequent political entrepreneur led consolidation around a new economic orthodoxy, should enable us predict that a third order change in economic policy is coming - that a critical juncture is coming. Ideational change is itself the bridge between economic crisis and subsequent economic policy change.

By situating Ireland in a comparative context we see how radical changes in economic policy can have certain commonalities, irrespective of country size, or political structure. The late $1950 \mathrm{~s}$ in Ireland witnessed a dramatic shift in economic policy, a change in some respects more radical than that in America under Reagan. Economic crisis led to the collapse of the ideas underlying protectionism. Lemass, influenced by Whitaker, outside influences, and failed protectionism, assumed the role of political entrepreneur, fostering an alternative set of ideas. Around these ideas change agent consensus developed, leading to their consolidation. As in America more than 20 years later, a political entrepreneur's championing of new ideas in the political arena led to a critical juncture in economic policy. Leamss altered the setting, instruments, and hierarchy of goals behind Irish economic policy. The absence of a political entrepreneur in Sweden in 1982, despite economic crisis, left the ideational foundations of existing policy intact, and resulted in only a first order change in economic policy there.

The economic policy changes instituted by Lemass served as a cornerstone for Irish economic policy going forward. Even the economic policies introduced in Ireland during the crisis years of the mid-1980s were framed with the context established by Lemass. The idea of Ireland as a small, open, and outward looking economy has formed the ideational foundations of all our economic policies since the late 1950s. The country's status as the world's most open economy is elegant confirmation of this, and a glowing tribute to the vision of Lemass half a century after he first articulated it.

This paper draws upon crisis, ideational, and institutional literature, to create a framework capable not only of analysing macro-economic policy change, but other policy change also. The framework could be used to predict policy outcomes in fields as diverse as foreign policy, democratisation, gender mainstreaming, and social and/or environmental policy. Researchers will no longer have to wait decades to declare an event a critical juncture. This framework broadens the applicability of the critical juncture concept, deepens its incisiveness, and contributes to a better understanding of policy change. 


\section{References}

Ahlén, Kristina. 1989. "Swedish Collective Bargaining Under Pressure: Inter-union Rivalry and Incomes Policies." British Journal of Industrial Relations 23: 3: 330346.

Bank of England. 1971. Bank of England Quarterly Bulletin. Vol. 11, No. 1.

Blondel, Jean. 1995. Comparative Government: An Introduction. (2 $2^{\text {nd }}$ ed.) New York: Harvester Wheatsheaf.

Blyth, Mark. 1997. "Moving the Political Middle: Redefining the Boundaries of State Action”, The Political Quarterly; 68:3, 217-314.

Blyth, Mark. 2002. Great Transformations: Economic Ideas and Institutional Change in the Twentieth Century. Cambridge University Press: Cambridge.

Casper, Gretchen, and Michelle M. Taylor. 1996. Negotiating Democracy: Transitions from Authoritarian Rule. Pittsburgh: University of Pittsburgh Press.

Christensen, T. 1997. "Utviklingen av direktoratene - aktører, tenkning og organisasjons-former," in T.Christensen and M. Egeberg, (eds.), Forvaltningskunnskap. Oslo: Tano.

Collier, R. B., and D. Collier. 1991. Shaping the Political Arena: Critical Junctures, the Labour Movement, and Regime Dynamics in Latin America. Princeton, NJ: Princeton University Press.

Collier, David. 1997. "Comparative Method in the 1990s", APSA-CP: Newsletter of the APSA Organised Section in Comparative Politics, 9:1, 1-5.

Cortell, Andrew P., and Susan Peterson. 1999. “Altered States: Explaining Domestic Institutional Change”, British Journal of Political Science, 29, 177-203.

Dahl, Robert. 1961. Who Governs? Democracy and Power in an American City. New Haven, CT: Yale University Press.

Dark, Taylor E., 1999. The Unions and the Democrats: An Enduring Alliance. London: Ithaca.

D’Souza, Dinesh. 1997. Ronald Reagan: How an Ordinary Man Became an Extraordinary Leader. New York: The Free Press.

National Institute of Economic and Social Research. 1970. Quarterly Economic Commentary. No. 1.

Feldstein, Martin. 1994. American Economic Policy in the 1980s. Chicago: University of Chicago Press. 
Gal, John, and David Bargal. 2002. "Critical Junctures, Labour Movements and the Development of Occupational Welfare in Israel”, Social Problems, 49:3, 432-454.

Garrett, Geoffrey, and Peter Lange. 1995. "Internationalization, Institutions, and Political Change", International Organization, 49:4, 627-655.

Garvin, T. 1982. The Evolution of Irish Nationalist Politics. Dublin: Gill and Macmillan.

Girvin, Brian. 1994. "Trade Unions and Economic Development," in Donal Nevin, (ed.), Trade Union Century. Cork: Mercier Press.

Golob, Stephanie. 2003. "Beyond the Policy Frontier: Canada, Mexico, and the Ideological Origins of NAFTA", World Politics, 55:3, 361-398.

Gorges, M. J. 2001. "The New Institutionalism and the Study of the European Union: The Case of the Social Dialogue”, West European Politics, 24:4, 152-168.

Greener, Ian. 2001. "Social Learning and Macroeconomic Policy in Britain." Journal of Public Policy 21: 133-152.

Hadenius, Stig. 1997. Swedish Politics During the 20 $0^{\text {th }}$ Century - Conflict and Consensus. Stockholm: Svenska Institute.

Haggard, Stephan. 1988. "The Institutional Foundations of Hegemony: Explaining the Reciprocal Trade Agreements Act of 1934," International Organization, 42:1, 91119.

Haggard, Stephen. 2003. Economic Crisis and Corporate Restructuring in Korea: Reforming the Chaebol. Cambridge: Cambridge University Press.

Haggard, Stephen, and Robert R. Kaufman. 1995. The Political Economy of Democratic Transitions. Princeton: Princeton University Press.

Hall, Peter A., ed. 1989. The Political Power of Economic Ideas: Keynesianism across Nations. Princeton: Princeton University Press.

Hall, Peter A. 1993. "Policy Paradigms, Social Learning, and the State: The Case of Economic Policy Making in Britain”, Comparative Politics, 25:3, 275-296.

Hodgkinson, Brian. 1971. "General View”, British Economic Survey, 1:1, 1-4.

Hogan, J. W. 2005. "Testing for a Critical Juncture: Change in the ICTU's Influence over Public Policy in 1959”, Irish Political Studies, 20:3, 23-43.

Hogan, J. W. 2006. "Remoulding the Critical Junctures Approach", Canadian Journal of Political Science, 39:3, 657-679.

Horgan, John. 1997. Seán Lemass: The Enigmatic Patriot. Dublin: Gill \& Macmillan. 
Jones, Maldwyn A. 1995. The Limits of Liberty: American History 1607 - 1992. ( $2^{\text {nd }}$ ed.) Oxford: Oxford University Press.

Karl, Terry Lynn. 1997. The Politics of Plenty: Oil Booms and Petro-States. Berkeley: University of California Press.

Kingdon, John. 1995. Agendas, Alternatives, and Public Policy. 2nd ed. New York: Harper.

Krugman, Paul A. 1990. The Age of Diminished Expectations: US Economic Policy in the 1990s. Cambridge, MA: MIT Press.

Legro, Jeffrey W. 2000. "The Transformation of Policy Ideas", American Journal of Political Science, 44:3, 419-432.

Lieberman, Evan S. 2001. "Causal Inference in Historical Institutional Analysis: A Specification of Periodization Strategies", Comparative Political Studies, 34, 10111035.

Lijphart, Arend. 1999. Patterns of Democracy: Government Forms and Performance in Thirty-six Countries. New Haven, Conn: Yale University Press.

Mahler, Gregory S. 1992. Comparative Politics: An institutional and Cross-national Approach. Englewood Cliffs, NJ: Prentice Hall.

Mahoney, James. 2000. "Path Dependence in Historical Sociology", Theory and Society, 29:4, 507-548.

Mahoney, James. 2001. "Path Dependent Explanations of Regime Change: Central America in Comparative Perspective", Studies in Comparative International Development, 36:1, 111-141.

Mahoney, James. 2003. "Long-Run Development and the Legacy of Colonialism in Spanish America", American Journal of Sociology, 109:1, 50-106.

Martin, A. 2000. "The Politics of Macroeconomic Policy and Wage Negotiations in Sweden." In Unions, Employers, and Central Banks, eds. Torben Iversen, Jonas Pontussson, and David Soskice. New York: Cambridge University Press.

Mayer, Lawrence C., John H. Burnett and Suzanne Ogden. 1993. Comparative Politics: Nations and Theories in a Changing World. Englewood Cliffs, N.J: Prentice Hall.

McCarthy, Charles. 1973. The Decade of Upheaval: Irish Trade Unions in the 1960s. Dublin: Institute of Public Administration.

McNamara, Kathleen R. 1998. The Currency of Ideas: Monetary Politics in the European Union. Ithaca: Cornell University Press. 
Mitchell, R.B. 1998. International Historical Statistics: The Americas 1750-1993. (4th ed.) Basingstoke: Macmillan.

Murphy, Gary. 1997. "Government, Interest Groups and the Irish Move to Europe", Irish Studies in International Affairs, 8, 57-68.

O’Day, Alan. 2000. "Nationalism and Economic Question in Twentieth Century Ireland," in Teichova, Alice et al., (eds.), Economic Change and the National Question in Twentieth Century Europe. Cambridge University Press, Cambridge.

O’Donnell, Rory. 1998. Ireland's Economic Transformation: Industrial Policy, European Integration and Social Partnership.

Ó’Gráda, Cormac, and Kevin O’Rourke. 1995. "Economic Growth: Performance and Explanations," in John W. O'Hagan, (ed.), The Economy of Ireland: Policy and Performance of a Small European Country. Dublin: Gill and Macmillan.

Oliver, Michael J. and Hugh Pemberton. 2004. "Learning and Change in 20thCentury British Economic Policy." Governance 17: 3: 415-441.

Organisation for Economic Cooperation and Development. 1970. The United Kingdom 1970. Paris: OECD.

Organisation for European Economic Cooperation. 1961. Ireland 1961. Paris: OEEC.

Organisation for Economic Cooperation and Development. 1962. Ireland 1962. Paris: OECD.

Organisation for Economic Cooperation and Development. 1982. Sweden 1982. Paris: OECD.

Organisation for Economic Cooperation and Development. 1984. Sweden 1984. Paris: OECD.

Organisation for Economic Cooperation and Development. 1970. The United Kingdom 1970. Paris: OECD.

Organisation for Economic Cooperation and Development. 1982. The United States of America 1982. Paris: OECD.

Peillon, Michael. 1995. "Interest Groups and the State in the Republic of Ireland," 360-378, in Patrick Clancy, (ed.), Irish Society: Sociological Perspectives. Dublin: IPA.

Pemberton, Hugh. 2000. "Policy Networks and Policy Learning: UK Economic Policy in the 1960s and 1970s." Public Administration 78: 4: 771-792.

Pierson, Paul. 2000. "Increasing Returns, Path Dependency, and the Study of Politics”, American Political Science Review, 94:2, 251-267. 
Pierson, Paul. 2004. Politics in Time: History, Institutions, and Social Analysis. Princeton University Press: Princeton, NJ.

Pierson, Paul and Theda Skocpol. 2002. "Historical Institutionalism in Contemporary Political Science," unpublished paper, 1-33.

Sheingate, A. D. 2003. "Political Entrepreneurship, Institutional Change, and American Political Development." Studies in American Political Development 17: 185-203.

Siven, Claes-Henric. 1984. "The Political Economy of Sweden in the 1970s." Department of Economics - University of Stockholm, Research Papers in Economics, No. 1.

Solimano, A. 2005. Political Crises, Social Conflict and Economic Development: The Political Economy of the Andean Region. Cheltenham: Edward Elgar

Steinmo, Sven. 1989. "Political Institutions and Tax Policy in the United States, Sweden, and Britain", World Politics, 41:4, 500-535.

Stevenson, Randolph T. 2001. "The Economy and Policy Mood: A Fundamental Dynamic of Democratic Politics?" American Journal of Political Science, 45:3, 620633.

Streeck, Wolfgang and Kathleen Thelen. 2005. "Introduction: Institutional Change in Advanced Political Economies," in Kathleen Thelen and Wolfgang Steeck, (eds.), Beyond Continuity: Institutional Change in Advanced Political Economies. Oxford: Oxford University Press.

Suárez, Sandra. 2001. "Political and Economic Motivations for Labor Control: A Comparison of Ireland, Puerto Rico, and Singapore", Studies in Comparative International Development, 36:2, 54-81.

Tansey, P. 1998. Ireland at Work: Economic Growth and the Labour Market, 19871997. Dublin: Oak Tree Press.

Taylor, John B. 1993. Macroeconomic Policy in the World Economy. New York: W.W. Norton.

Taylor, John B. 1995. "Changes in American Economic Policy in the 1980s: Watershed or Pendulum Swing?" Journal of Economic Literature, 33: 2, 777-784.

Thelen, Kathleen, and Sven Steinmo. 1992. "Historical Institutionalism in Comparative Politics," in Sven Steinmo, Kathleen Thelen, and Frank Longstreth, (eds.), Structuring Politics: Historical Institutionalism in Comparative Analysis. Cambridge: Cambridge University Press.

Thelen, Kathleen. 1999. "Historical Institutionalism in Comparative Politics", Annual Review of Political Science, 2, 369-404. 
Thelen, Kathleen. 2004. How Institutions Evolve: The Political Economy of Skills in Germany, Britain, the United States and Japan. Cambridge: Cambridge University Press.

Walsh, J. I. 2006. "Policy Failure and Policy Change: British Security Policy After the Cold War." Comparative Political Studies 39: 490-518.

Wayne, Stephen J. 1992. The Road to the White House 1992: The Politics of Presidential Elections. New York: St. Martin's Press.

${ }^{1}$ The Irish Times, 25 June, 1959

${ }^{2}$ Dáil Eireann, Vol. 171, 2 December, 1958.

${ }^{3}$ ibid., 16 June, 1980, Vol. 115, No. 24, p. 48.

${ }^{4}$ ibid., 28 July, 1980, Vol. 116, No. 4, p. 44

${ }^{5}$ The New York Times, 2 September 1980, p. 12.

${ }^{6}$ The Washington Post, 20 November 1980, p. B1.

${ }^{7}$ Time International, 16 June, 1980, Vol. 115, No. 24, p. 50.

${ }^{8}$ The Economist, 28 August, 1982, p. 41.

${ }^{9}$ The New York Times, 20 September, p. 3.

${ }^{10}$ Time International, 20 September, 1982, Vol. 120, No. 38, p. 32.

${ }^{11}$ The New York Times, 20 September, p. 3.

${ }^{12}$ Budget, 1958, p. 8.

${ }^{13}$ The Irish Independent, 24 June, 1959.

${ }^{14}$ Dáil Eireann, Vol. 175, 3 June, 1959.

${ }^{15}$ Time International, 28 July, 1980, Vol. 116, No. 4, p. 44

${ }^{16}$ The Washington Post, Business and Finance, 31 August, p. L1.

${ }^{17}$ Time International, 29 September, 1980, Vol. 116, No. 13, p. 17.

${ }^{18}$ ibid., 29 September, 1980, Vol. 116, No. 13, p. 45.

${ }^{19}$ ibid., 28 August, 1980, p. 9.

${ }^{20}$ Time International, 3 November, 1980, Vol. 116, No. 18, p. 17.

${ }^{21}$ The Washington Post, 16 February, 1981, p. A1.

${ }^{22}$ http://www.const.sns.se/swedishpolitics/.

${ }^{23}$ Financial Times, 18 September, 1982, p. 15. 
${ }^{24}$ The Washington Post, 21 September, 1982, p. A15.

${ }^{25}$ Time International, 20 September, 1982, Vol. 120, No. 38, p. 32.

${ }^{26}$ The Washington Post, 21 September, 1982, p. A15.

${ }^{27}$ The New York Times, 20 September, 1982, p. 3.

${ }^{28}$ ibid., 21 September, 1982, p. 3.

${ }^{29}$ Financial Times, 12 October, 1982, p. 1.

${ }^{30}$ The Washington Post, 8 October, 1982, p. A16. 